\title{
Can cognitive behavioural therapy based strategies be integrated into physiotherapy for the prevention of chronic low back pain? A systematic review
}

\author{
Emanuel Brunner, Amber De Herdt, Philippe Minguet, Se-Sergio Baldew \& \\ Michel Probst
}

To cite this article: Emanuel Brunner, Amber De Herdt, Philippe Minguet, Se-Sergio Baldew \& Michel Probst (2013) Can cognitive behavioural therapy based strategies be integrated into physiotherapy for the prevention of chronic low back pain? A systematic review, Disability and Rehabilitation, 35:1, 1-10, DOI: 10.3109/09638288.2012.683848

To link to this article: http://dx.doi.org/10.3109/09638288.2012.683848

Published online: 21 May 2012.

Submit your article to this journal ๘

Lll Article views: 1628

Q View related articles $๘$

4 Citing articles: 2 View citing articles 준 


\title{
Can cognitive behavioural therapy based strategies be integrated into physiotherapy for the prevention of chronic low back pain? A systematic review
}

\author{
Emanuel Brunner ${ }^{1}$, Amber De Herdt ${ }^{1,2}$, Philippe Minguet ${ }^{1,2}$, Se-Sergio Baldew ${ }^{1}$ \& Michel Probst ${ }^{1,2}$ \\ ${ }^{1}$ Faculty of Kinesiology and Rehabilitation Science, KU Leuven, Leuven, Belgium and ${ }^{2}$ University Psychiatric Centre, KU Leuven, \\ Campus Kortenberg, Kortenberg, Belgium
}

\begin{abstract}
Purpose: The primary purpose was to detect randomized controlled trials investigating cognitive behaviour therapybased (CBT) treatments applied in acute/sub-acute low back pain (LBP). The secondary purpose was to analyse the methodological properties of the included studies, and to identify theory-based treatment strategies that are applicable for physiotherapists. Method: A systematic literature search was conducted using four databases. Risk of bias of included studies was assessed and the methodological properties summarized. In addition, content and treatment theory of detected CBT-based strategies were systematically analysed and classified into three distinctive concepts of CBT: operant, cognitive and respondent treatment. Finally, applicability of treatment strategies in physiotherapy practice was discussed. Results: Eight studies were included in the present systematic review. Half of the studies suffered from high risk of bias, and study characteristics varied in all domains of methodology, particularly in terms of treatment design and outcome measures. Graded activity, an operant treatment approach based on principles of operant conditioning, was identified as a CBT-based strategy with traceable theoretical justification that can be applied by physiotherapists. Conclusion: Operant conditioning can be integrated in ambulant physiotherapy practice and is a promising CBT-based strategy for the prevention of chronic LBP.
\end{abstract}

Keywords: Biopsychosocial model, psychosocial intervention, cognitive behavioural therapy, physical therapy, physiotherapy, lower back pain

\section{Introduction}

Management of low back pain (LBP) is a challenge for health care professionals as well as the health care system as

\section{Implications for Rehabilitation}

- Physiotherapist can integrate operant treatment approaches into their standard pain management for acute/sub-acute LBP.

- Graded activity, based on operant conditioning, is a promising treatment approach for the prevention of chronic LBP.

- Health care providers, other than only clinical psychologists, should deliver CBT- based treatment strategies, which aim to decrease pain behaviour by reinforcing exercise behaviour and active coping strategies.

a whole in industrialised countries. Approximately $20-56 \%$ of adults experience LBP at some time during a period of 1 year [1]. However, not every affected person consults health care professionals. In the UK, for example, LBP accounts for $6.4 \%$ of adult practitioner visits [2]. Most challenging is the sub-group, approximately $8 \%$ of the total patient population, which develops chronic LBP [3] and is listed as staying sick for more than 3 months after onset of the pain episode $[2,4]$. These patients account for $75 \%$ of the total costs for LBP [5], and are associated with poor rehabilitation outcomes [6]. Thus, the prevention of chronicity is the major goal in the management of acute/sub-acute LBP. Despite the priority of the issue, there is still a lack of clarity regarding best practice for the prevention of chronic LBP. Clinical guidelines for the management of acute/sub-acute LBP emphasise the importance of providing information regarding positive prognosis, advice to stay active, and discouragement of bed rest [7-9]. However, guidelines cannot provide health care professionals with specific advice regarding best practice for the pain management. In general, complementary and

Correspondence: Michel Probst, University Psychiatric Centre, KU Leuven, Campus Kortenberg, Leuvensesteenweg 517, Kortenberg B-3070, Belgium. Tel.: 003227580 578, Fax: 003227589 878. E-mail: michel.probst@faber.kuleuven.be

(Accepted April 2012) 
alternative treatments for acute/sub-acute LBP such as exercise therapy, spinal manipulation, acupuncture or massage therapy have insufficient evidence for long term functional improvements and to support one effective treatment over another [10]. This uncertainty with regard to best practice urges physiotherapists, like any other professionals involved in the management of LBP, to reconsider and eventually revise existing management approaches for the prevention of chronic LBP.

Non-specific LBP, can be defined as low back pain not attributed to recognisable or known specific pathology [7], or a physical disorder resulting in pain and disability. However, neither pain is as a direct physical consequence of dysfunction, nor does the pain automatically result in reduced function or disability [11]. The interaction between pain and disability is complex and influenced by many factors. The International Classification of Functioning, Disability and Health (ICF) maps disability as the result of an interaction between impairment of body function or structure, activity limitation and participation, all of which are influenced by contextual factors, environmental and personal factors [12]. The fear-avoidance model [13], a widely accepted model explaining the development and maintenance of a chronic pain syndrome, describes the influence of such personal or psychosocial factors. Psychosocial factors from the fear-avoidance model have been reported as being obstacles to recovery in LBP. These include catastrophizing [14,15], fear-avoidance beliefs [15-18], and depression $[19,20]$. By recognizing the importance of personal or psychosocial factors, it can be concluded that LBP and disability have a complex multi-dimensional nature that can only be understood and managed by a biopsychosocial model, which explains pain and disability as a result of factors from five domains, namely physical dysfunction, beliefs and coping, distress, illness behaviour, and social interaction [11]. Treatments involving physical and appropriate biopsychosocial approaches seem to be most promising for the secondary prevention of LBP [21]. This background raises questions regarding the application and provision of the biopsychosocial model in a standard primary care setting. Therapy settings show regional differences, but most patients consult their general practitioners and may receive complementary or alternative therapies provided by physiotherapists, occupational therapists, chiropractors, nurses or psychologists. In general, patients with acute/sub-acute LBP are rarely treated in a multi-disciplinary treatment setting. Therefore, all health care professionals are challenged to integrate psychosocial interventions as an integral part of a biopsychosocial model of care if they aim to deliver treatments promising to prevent chronic pain and disability.

Physiotherapists provide services to develop, maintain and restore maximum movement and functional ability, by using interventions, such as therapeutic exercise, functional training in self-care, or home management [22]. Physiotherapists have profound expertise in promoting physical activity, exercise and physical fitness. Based on the expertise in function- and activity-based interventions, it can be hypothesized that they are pre-destined for providing biopsychosocial treatment approaches by succeeding in combining functional, biomechanical and psychosocial interventions. An inter-disciplinary expert group at an international low back pain forum identified a clear need for health care professionals other than clinical psychologists to integrate psychosocial interventions in their routine pain management for acute/sub-acute nonspecific LBP, and formulated inexplicit objectives for such an intervention [23]. Such professionals may include physiotherapists, occupational therapists, chiropractors, nurses or general practitioners. Recently, the importance of embedding psychosocial perspectives within physiotherapy practice of low back pain was discussed [24], and a review outlined possible psychosocial interventions as part of a biopsychosocial model for treating sub-acute LBP [25]. To date, the content as well as the treatment theory of psychosocial interventions remains vague, despite the recognized importance of the issue. As a consequence of this, the clinical decision making process with regard to targeting adequate treatments for a patient is insufficient. In clinical practice, physiotherapists are challenged to identify psychosocial obstacles for recovering in acute/sub-acute LBP and to apply strategies promising to influence these obstacles afterwards. Therefore, more concrete references regarding the content of psychosocial interventions, as well as the theoretical justification is needed in order to improve clinical decision-making.

Cognitive behavioural therapy (CBT) is a promising treatment approach for influencing psychosocial factors in LBP. The concept is recognized as the most promising treatment approach for chronic LBP, particularly in terms of encouraging activity and exercise [26]. CBT is a psychotherapeutic treatment concept comprising elements of behavioural therapy mainly based on the principal of operant conditioning and elements from cognitive therapy. Describing or framing CBT for the treatment of LBP is challenging because it tends to be an umbrella term for a broad variety of interventions. But in general, these approaches all have a common aim which is to alter maladaptive thoughts, feelings and behaviour as well as dysfunctional sensory phenomena, and thereby the experience of pain [27]. The CBT concept for chronic LBP has been distinguished into three different treatment approaches: operant, cognitive, and respondent treatment [27,28].

Operant treatment is based on the operant conditioning theory described by Skinner [29]. This treatment approach aims to reinforce healthy behaviours and reduce pain behaviours by using an exercise quota for increasing general activity levels which are gradually built up towards a realistic predefined goal. Spouses and/or family members are integrated into the therapy whenever possible and instructed to promote well behaviours of the patient [30]. Cognitive treatment, based on the cognitive model from Beck [31], is designed to help patients modify maladaptive conceptualizations and dysfunctional beliefs about themselves and their disability [32]. Patients learn to identify negative emotions related to pain, stressful events and associated maladaptive thoughts [33]. In addition to this, they are taught to generate adaptive thoughts in order to 'counter' automatic negative cognitions [33]. Cognitive therapies often integrate imagery exercises, aimed at changing the pain experience by shifting attention to something other than bodily sensations [34]. Respondent 
treatment attempts to modify the physiological response system to pain. The theory of this approach is based on the assumption of a pain-tension cycle, where pain is viewed as cause and result of muscular tension [27]. Electromyographic (EMG) biofeedback and relaxation techniques are used to encourage the patient to identify tension-eliciting stimuli and to differentiate between muscle tension and relaxation [28].

It has been suggested that treatment theory can be helpful for improving rehabilitation practice and builds the basis for better clinical decision-making, whereby it is important to answer questions such as how, why, and for whom a certain treatment is effective $[35,36]$. Generally, this research wishes to contribute, in a systematic manner, to increasing clarity with regard to the content and treatment theory of psychosocial interventions for acute/sub-acute LBP. The primary purpose is to detect all randomized controlled trials (RCTs) investigating the effect of CBT-based treatments applied in acute/sub-acute LBP. The secondary purpose is to analyse the methodological properties of detected trials, and finally to find theory based treatment strategies that are applicable for physiotherapists.

\section{Methods}

\section{Literature search}

Studies were identified by a computer-generated search on Medline, Embase, PsycInfo, Cochrane Central Register of Controlled Clinical Trials (Central), and by citation tracking in relevant publications. Search strategies were designed for high sensitivity and included the following search terms: "randomized controlled trial" OR "controlled clinical trial" OR "randomized" OR "randomly" OR "trial” OR "groups"; AND "low back pain"; AND "behaviour therapy” OR "cognitive therapy" OR "cognitive behaviour therapy" OR "cognitive behavioural therapy". The literature search was updated on September, 2011 and was not restricted by language.

\section{Selection of studies}

Identified records were controlled for multiple hits and duplicates were manually removed. Titles and abstracts were screened for eligibility as a first step and if further information was needed the full texts were read. Articles were included if they fulfilled all of the following criteria:

- Randomized controlled trial (RCT).

- Non-specific LBP [7], lasting for less than 12 weeks.

- Reporting results from one or more outcome measures in the domains of pain symptom, back-pain related function, general well-being, disability, and patient satisfaction [37].

- Published between January 1992 and September 2011.

Articles were excluded if the pain duration was not reported, patients previously underwent lumbar surgery, had multiple musculoskeletal pain or pain complaints other than non-specific LBP.

\section{Risk of bias assessment and data extraction}

Independently, three review authors (E.B., A.D.H., P.M.) assessed the risk of bias in the included studies, using the 12 criteria for internal validity recommended by the Cochrane Back Review Group [38]. The total score was computed by addition of the criteria scored 'yes', and low risk of bias was defined as a total score higher than six [38]. In the case of unclear information, the authors of the RCT were contacted for additional information. Disagreement between the reviewers was discussed and resolved during the consensus meeting. It was not possible to blind the reviewers to authors, institution and journal. The same three review authors obtained the data extraction in the domain of treatment content, reported treatment theory, setting, intensity, and treatment provider, by using a data extraction file based on the recommendations of the Cochrane Back Review Group [38].

\section{Data analysis}

Methodological quality of included articles was measured by the assessment of risk of bias, and detection of potential sources of heterogeneity, such as characteristics of participants, interventions, control groups or outcome measures. A meta-analysis was considered for RCTs rated as having low risk of bias, and if the review team decided that the heterogeneity was acceptable for quantitative analysis. CBT-based treatments applied in the included studies were summarized in the domain of content, theoretical justification, intensity, and treatment provider. Treatments were finally classified into the following CBT approaches: operant, cognitive, respondent, or as a combination of these approaches. The following criteria needed to be satisfied for the classification into the various approaches: operant treatment required a form of graded activity program with exercise quota; cognitive treatment required at least one treatment element aiming to modify maladaptive thoughts to counter maladaptive cognitions related to pain or disability; and for respondent treatment, biofeedback or relaxation techniques were essential in order to be classified.

\section{Results}

\section{Identification of studies}

The search strategies on databases identified 426 records, and one additional record was additionally identified through citation tracking [39]. Following the removal of duplicated records, 266 were screened for eligibility by reading title and abstract, and 120 full texts were read for the final control of eligibility. Eight studies [39-46] met all criteria and were included in the systematic review (see Figure 1).

\section{Methodological quality and study characteristics}

Results from the assessment of risk of bias are summarized in Table I. Six RCTs did not contain sufficient information on one or more criteria. Authors of five articles were contacted for additional information. One author group (Johnstone et al., 2004 [40]) could not been contacted because current contact details were not detectable. Only two authors replied and provided additional information. Four studies (50\%) were rated as having low risk of bias, and thereby considered for inclusion in quantitative analysis. 


\section{E. Brunner et al.}

Study characteristics differed in all domains of study design. Participants in three RCTs were not explicitly defined in terms of non-specific LBP, but it could be assumed that the included participants did not have a specific pathology. Four studies considered the risk factors for developing chronicity as an inclusion criterion, which were assessed with two different instruments, namely the Identification Algorithm for Chronic Disability [47], and the modified Zung and Somatic Perception Questionnaire [48]. The other studies did not account for risk factors for developing chronicity as an inclusion criterion.

Interventions of included studies differ appreciably. Treatment characteristics are therefore summarized in more detail later. Control groups consisted of standard care in five studies, consisting of two different forms of standardized physiotherapy or standard instructional videotape. The

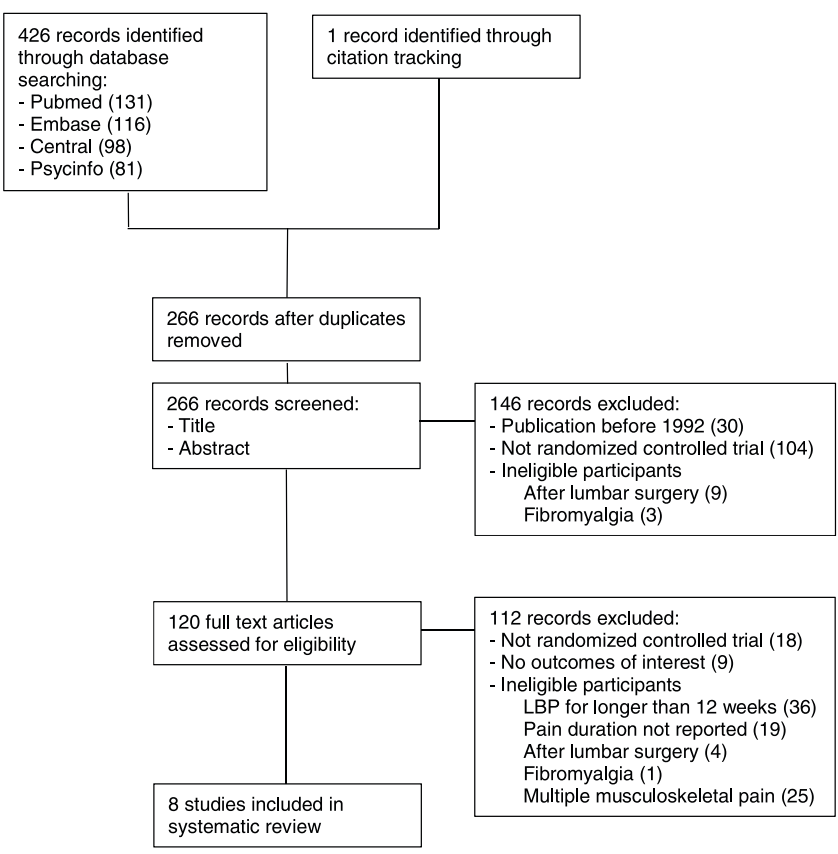

Figure 1. Study flow diagram. highest heterogeneity was found in the domain of outcome measures. Pain symptoms were assessed in seven studies, whereby two modes of measurement were used, namely the Million Visual Analogue Scale (MVAS) [49] and Visual Analogue Scales (VAS). Disability was assessed in four studies using different methods for measuring return to work and work absenteeism such as time off work or sick leave days. The domain of backrelated function was assessed in four studies by using the Roland Morris Disability Questionnaire (RMDQ) [50] or the Oswestry Disability Index (ODI), where the version of the ODI used was not reported. One included study assessed outcomes with a short-term follow up, another study with an intermediate follow up at 4.5 months after baseline measure. The other studies measured long-term outcomes 12 months after baseline. Outcome measures are inconsistent in the total group of included studies as well as in the subgroup of studies with low risk of bias. Quantitative analysis was not indicated because of the detected heterogeneity in the studies with low risk of bias.

\section{Treatment characteristics}

Treatment characteristics are summarized in Table III. The CBT-based interventions were all provided within an ambulant treatment setting in the USA and in four different European countries. Three treatment programmes were carried out at the same institution in Dallas, Texas (USA). In contrast to the other interventions, only the cognitive behavioural videotape was watched individually at home. Three treatment programmes are characterised by high treatment intensities of 26 or more treatment sessions lasting 45-60 min, and were carried out by multi-disciplinary teams or by physiotherapists in occupational health services. The other treatment programmes were characterised by intensities of up to 9 sessions and were provided independently by physiotherapists, or in co-operation with other health care providers. The profession of the treatment provider was not appropriately defined in one study. Physiotherapists in one RCT received special training before delivering treatments, in the form of a 2 day course where they were trained for competency in biopsychosocial model of care.

Table I. Summery assessment of risk of bias.

\begin{tabular}{|c|c|c|c|c|c|c|c|c|c|c|c|c|c|c|}
\hline & $\begin{array}{l}\text { Ad- } \\
\text { equate } \\
\text { method } \\
\text { of ran- } \\
\text { domiza- } \\
\text { tion? }\end{array}$ & $\begin{array}{l}\text { Con- } \\
\text { cealed } \\
\text { treat- } \\
\text { ment } \\
\text { alloca- } \\
\text { tion? }\end{array}$ & $\begin{array}{c}\text { Patient } \\
\text { blinded } \\
\text { to inter- } \\
\text { vention? }\end{array}$ & $\begin{array}{c}\text { Care } \\
\text { provider } \\
\text { blinded } \\
\text { to inter- } \\
\text { vention? }\end{array}$ & $\begin{array}{c}\text { Out- } \\
\text { come } \\
\text { assessor } \\
\text { blinded } \\
\text { to inter- } \\
\text { vention? }\end{array}$ & $\begin{array}{l}\text { Drop- } \\
\text { out rate } \\
\text { de- } \\
\text { scribed } \\
\text { and } \\
\text { accept- } \\
\text { able? }\end{array}$ & $\begin{array}{l}\text { Par- } \\
\text { ticipants } \\
\text { analysed } \\
\text { into } \\
\text { group to } \\
\text { which } \\
\text { they } \\
\text { were al- } \\
\text { located? }\end{array}$ & $\begin{array}{l}\text { Reports } \\
\text { free of } \\
\text { sugges- } \\
\text { tion of } \\
\text { selective } \\
\text { outcome } \\
\text { report- } \\
\text { ing? }\end{array}$ & $\begin{array}{c}\text { Groups } \\
\text { similar } \\
\text { at base- } \\
\text { line? }\end{array}$ & $\begin{array}{c}\text { Co- in- } \\
\text { terven- } \\
\text { tions } \\
\text { avoided } \\
\text { or simi- } \\
\text { lar? }\end{array}$ & $\begin{array}{c}\text { Compli- } \\
\text { ance ac- } \\
\text { ceptable } \\
\text { in all } \\
\text { groups? }\end{array}$ & $\begin{array}{l}\text { Timing } \\
\text { of the } \\
\text { outcome } \\
\text { - assess- } \\
\text { ment } \\
\text { in all } \\
\text { groups? }\end{array}$ & $\begin{array}{c}\text { Result } \\
\text { (scored } \\
\text { 'yes') }\end{array}$ & $\begin{array}{c}\text { Risk } \\
\text { of } \\
\text { bias }^{\S}\end{array}$ \\
\hline Rogerson et al., 2010 & $?$ & $?$ & $\mathrm{~N}$ & $\mathrm{~N}$ & $\mathrm{~N}$ & $\mathrm{~N}$ & $\mathrm{~N}$ & $\mathrm{~N}$ & $\mathrm{Y}$ & $\mathrm{N}$ & $\mathrm{N}$ & $\mathrm{Y}$ & 2 & $\mathbf{H}$ \\
\hline Whitfill et al., 2010 & $?$ & $?$ & $\mathrm{~N}$ & $\mathrm{~N}$ & $\mathrm{~N}$ & $\mathrm{~N}$ & $\mathrm{~N}$ & $\mathrm{~N}$ & $\mathrm{Y}$ & $?$ & $?$ & $\mathrm{Y}$ & 2 & $\mathbf{H}$ \\
\hline Newcomer et al., 2008 & $\mathrm{Y}$ & $\mathrm{N}$ & $\mathrm{Y}$ & $\mathrm{Y}$ & $\mathrm{Y}$ & $\mathrm{Y}$ & $\mathrm{Y}$ & $\mathrm{Y}$ & $\mathrm{Y}$ & $\mathrm{Y}$ & $\mathrm{N}^{*}$ & $\mathrm{Y}$ & 10 & $\mathbf{L}$ \\
\hline Steenstra et al., 2006 & $\mathrm{Y}$ & $\mathrm{Y}$ & $\mathrm{N}$ & $\mathrm{N}$ & $\mathrm{N}$ & Y & Y & $\mathrm{Y}$ & $\mathrm{Y}$ & $\mathrm{Y}$ & $\mathrm{N}$ & Y & 8 & $\mathbf{L}$ \\
\hline Hay et al., 2005 & Y & $\mathrm{Y}$ & $\mathrm{Y}$ & $\mathrm{N}$ & $\mathrm{Y}$ & $\mathrm{Y}$ & $\mathrm{Y}$ & $\mathrm{Y}$ & $\mathrm{Y}$ & $\mathrm{N}$ & $\mathrm{Y}$ & $\mathrm{Y}$ & 10 & $\mathbf{L}$ \\
\hline Storheim et al., 2003 & $\mathrm{Y}$ & $\mathrm{Y}$ & $\mathrm{N}$ & $\mathrm{N}$ & $\mathrm{N}$ & $\mathrm{N}$ & $\mathrm{Y}$ & $\mathrm{N}$ & $\mathrm{Y}$ & $\mathrm{Y}^{*}$ & $\mathrm{Y}^{*}$ & $\mathrm{Y}$ & 7 & $\mathbf{L}$ \\
\hline Johnstone et al., 2004 & $\mathrm{Y}$ & $?$ & $\mathrm{~N}$ & $\mathrm{~N}$ & $\mathrm{~N}$ & $\mathrm{~N}$ & $\mathrm{Y}$ & $\mathrm{Y}$ & $\mathrm{N}$ & $?$ & $?$ & $\mathrm{Y}$ & 4 & $\mathbf{H}$ \\
\hline Gatchel et al., 2003 & $\mathrm{Y}$ & $\mathrm{Y}$ & $\mathrm{N}$ & $\mathrm{N}$ & $\mathrm{N}$ & $\mathrm{N}$ & $\mathrm{Y}$ & $\mathrm{N}$ & $?$ & $?$ & $?$ & $\mathrm{Y}$ & 4 & $\mathbf{H}$ \\
\hline
\end{tabular}

$\mathrm{Y}=$ criteria fulfilled; $\mathrm{N}=$ criteria not fulfilled;? = unclear information; *authors provided additional information; ${ }^{\S}$ rating of risk of bias; $\mathrm{H}=$ high risk of bias (less than 6 of 12 criteria scored 'yes'); $\mathrm{L}=$ low risk of bias (at least 6 of 12 criteria scored 'yes'). 
Table II. Study characteristics of included articles.

\begin{tabular}{|c|c|c|c|c|}
\hline$\underline{\text { Study }}$ & Participants & CBT-based intervention & Control group & Outcome measures $^{\S}$ \\
\hline Rogersonet al., 2010 & $\begin{array}{l}\text { - LBP, }<10 \text { weeks } \\
\text { - High risk for chronic } \\
\text { disability }{ }^{\pi} \\
\text { - Age: } 19-65 \text { years }\end{array}$ & $\begin{array}{l}\text { Cognitive behavioural } \\
\text { therapy and physical therapy } \\
(\mathrm{N}, 121)\end{array}$ & Standard care $(\mathrm{N}, ?)$ & $\begin{array}{l}\text { - Pain symptoms: MVAS } \\
\text { - Follow up: } 12 \text { months }\end{array}$ \\
\hline Whitfill et al., 2010 & $\begin{array}{l}\text { - LBP, }<12 \text { weeks } \\
\text { - High risk for chronic } \\
\text { disability }{ }^{\pi} \\
\text { - Age: } 18-65 \text { years }\end{array}$ & $\begin{array}{l}\text { Early intervention plus work } \\
\text { transition }(\mathrm{N}, 90)\end{array}$ & Standard care $(\mathrm{N}, 52)$ & $\begin{array}{l}\text { - Pain symptoms: VAS } \\
\text { (scale not defined) } \\
\text { - Disability: return to work } \\
\text { - Well being: SF-36 } \\
\text { - Follow up: } 12 \text { months }\end{array}$ \\
\hline Newcomer et al., 2008 & $\begin{array}{l}\text { - Nonspecific LBP, }<12 \\
\text { weeks } \\
\text { - Age: } 18-70 \text { years }\end{array}$ & $\begin{array}{l}\text { Cognitive behavioural video- } \\
\text { tape }(\mathrm{N}, 110)\end{array}$ & $\begin{array}{l}\text { Standard instructional } \\
\text { videotape }(\mathrm{N}, 110)\end{array}$ & $\begin{array}{l}\text { - Back function: ODI } \\
\text { - Follow up: } 12 \text { months }\end{array}$ \\
\hline Steenstra et al., 2006 & $\begin{array}{l}\text { - Nonspecific LBP } \\
\text { - Age: } 18-65 \text { years } \\
\text { - } 8 \text { weeks sick listed due to } \\
\text { LBP }\end{array}$ & $\begin{array}{l}\text { Graded activity program } \\
(\mathrm{N}, 28)\end{array}$ & $\begin{array}{l}\text { Standard care, including } \\
\text { work place intervention } \\
(\mathrm{N}, 32)\end{array}$ & $\begin{array}{l}\text { - Pain symptoms: VAS (pain } \\
\text { at present) } \\
\text { - Disability: return to work, } \\
\text { sick leave day } \\
\text { - Back function: RMDQ } \\
\text { - Well being:EuroQol }{ }^{\dagger} \\
\text { - Follow up: } 12 \text { months }\end{array}$ \\
\hline Hay et al., 2005 & $\begin{array}{l}\text { - Nonspecific LBP, < } 12 \\
\text { weeks } \\
\text { - Age: } 18-64 \text { years }\end{array}$ & $\begin{array}{l}\text { Biopsychosocial pain man- } \\
\text { agement }(\mathrm{N}, 201)\end{array}$ & $\begin{array}{l}\text { Manual physiotherapy } \\
(\mathrm{N}, 201)\end{array}$ & $\begin{array}{l}\text { - Pain symptoms: VAS (pain } \\
\text { at present) } \\
\text { - Disability: time off work } \\
\text { - Back function: RMDQ } \\
\text { - Follow up: } 12 \text { months }\end{array}$ \\
\hline Storheim et al., 2003 & $\begin{array}{l}\text { - Nonspecific LBP, 8-12 } \\
\text { weeks } \\
\text { - Age: } 20 \text {-60 years } \\
\text { - Sick listed due to LBP }\end{array}$ & $\begin{array}{l}\text { Cognitive intervention } \\
(\mathrm{N}, 34)\end{array}$ & Standard care $(\mathrm{N}, 29)$ & $\begin{array}{l}\text { - Pain symptoms: VAS (pain } \\
\text { at present) } \\
\text { - Back function: RMDQ } \\
\text { - Follow up: } 4.5 \text { months }\end{array}$ \\
\hline Johnstone et al., 2004 & $\begin{array}{l}\text { - Nonspecific LBP, }<6 \text { weeks } \\
\text { - Psychosocial distress }{ }^{\Delta} \\
\text { - Age: } 18-65 \text { years }\end{array}$ & $\begin{array}{l}\text { Cognitive behavioural } \\
\text { therapy integrated in physio- } \\
\text { therapy }(\mathrm{N}, 6)\end{array}$ & Physiotherapy $(\mathrm{N}, 6)$ & $\begin{array}{l}\text { - Pain symptoms; VAS (pain } \\
\text { at present) } \\
\text { - Back function: RMDQ } \\
\text { - Follow up: approximately } 1 \\
\text { month }\end{array}$ \\
\hline Gatchel et al., 2003 & $\begin{array}{l}\text { - LBP, }<10 \text { weeks } \\
\text { - High risk for chronic } \\
\text { disability } \\
\text { - Age: } 18-65 \text { years }\end{array}$ & $\begin{array}{l}\text { Functional restoration } \\
(\mathrm{N}, 22)\end{array}$ & Standard care $(\mathrm{N}, 48)$ & $\begin{array}{l}\text { - Pain symptoms: VAS (pain } \\
\text { last } 3 \text { months) } \\
\text { - Disability: return to work } \\
\text { - Follow up: } 12 \text { months }\end{array}$ \\
\hline
\end{tabular}

Operant treatment approaches differ in the content, intensity and theoretical justification of the intervention. One graded activity programme, which was based on the theory of operant conditioning, was comprised of general strengthening and endurance exercises which were gradually increased towards a pre-defined exercise goal according to the time contingent principle. One treatment program used pacing strategies for promoting a gradual return to normal activities. Operant treatment approaches were combined with cognitive treatment elements such as the explanation of pain mechanisms and distress, encouragement of positive coping strategies, and reducing fear avoidance. Another treatment consisted of a combination of cognitive, operant, and respondent approaches, whereby a comprehensive theoretical justification of the strategies could not be detected because the report referred to several sources, which contained broad descriptions of CBT-based interventions. This combined CBT therapy encompassed the following approaches: operant treatment in form of physical exercises to functional quotas, and pacing; as well as cognitive treatment for the exploration of thoughts, beliefs about pain in order to influence thoughts and beliefs on behaviour; and respondent treatment such as breathing and relaxation techniques that were taught in therapy and practiced at home.

The educational videotape used specific concepts from "The Back Book" [51]. These included the emphasis of movement and use of the body, recommendation of moderate physical activity as the best treatment for maintaining back muscles strength and tone, and the promotion of planned daily physical exercises. Additionally, the anatomy of the lumbar spine and pain-provoking structures were briefly outlined. Information was given regarding the positive prognosis of acute LBP, and the strategy of modelling was used in the form of patients who discussed their successful active coping strategies. The intervention aims to modify maladaptive pain beliefs and was classified as cognitive treatment. Treatment theory of the videotape was not reported. Two similar treatment programmes combined cognitive and respondent approaches. These two programmes are based on the same 
Table III. Summary of CBT-based treatment characteristics.

\begin{tabular}{|c|c|c|c|c|c|c|}
\hline Study & Content of treatment ${ }^{\S}$ & Theory $^{\pi}$ & Approach $^{\dagger}$ & Setting $^{\Omega}$ & Intensity & $\begin{array}{l}\text { Treatment } \\
\text { provider }\end{array}$ \\
\hline $\begin{array}{l}\text { Rogerson et al., } \\
2010\end{array}$ & $\begin{array}{l}\text { - Coping skills training } \\
\text { - Physical therapy (not standardized) } \\
\text { - Relaxation and biofeedback }\end{array}$ & Not reported & Respondent & $\begin{array}{l}\text { Ambulant; in } \\
\text { Dallas, Texas } \\
\text { (USA) }\end{array}$ & 6-9 sessions & $\begin{array}{l}\text { - Clinical psy- } \\
\text { chologist } \\
\text { - Physiothera- } \\
\text { pist }\end{array}$ \\
\hline $\begin{array}{l}\text { Whitfill et al., } \\
2010\end{array}$ & $\begin{array}{l}\text { - Coping skills, distraction techniques } \\
\text { - Stretching and exercises for strength, } \\
\text { endurance and range of motion } \\
\text { - Stress management/biofeedback } \\
\text { - Work transition (help address work } \\
\text { condition) }\end{array}$ & $\begin{array}{l}\text { Functional restora- } \\
\text { tion [52]Psychoso- } \\
\text { cial approaches [53] }\end{array}$ & $\begin{array}{l}\text { Cognitive- } \\
\text { respondent }\end{array}$ & $\begin{array}{l}\text { Ambulant; in } \\
\text { Dallas, Texas } \\
\text { (USA) }\end{array}$ & $\begin{array}{l}\text { - Max } 26 \text { ses- } \\
\text { sions( } 45 \text { min })- \\
2 \text { interdisci- } \\
\text { plinary team } \\
\text { conferences }\end{array}$ & $\begin{array}{l}\text { Multidisci- } \\
\text { plinary team }\end{array}$ \\
\hline $\begin{array}{l}\text { Newcomer et al., } \\
2008\end{array}$ & $\begin{array}{l}\text { Cognitive behavioural videotape, with } \\
\text { concepts from 'The Back Book': } \\
\text { - Anatomy of lumbar spine, pain- } \\
\text { provoking structures } \\
\text { - Encouraging physical activity, } \\
\text { exercises } \\
\text { - Information regarding prognosis of } \\
\text { LBP } \\
\text { - Modelling by successful patients }\end{array}$ & Not reported & Cognitive & $\begin{array}{l}\text { At home; in } \\
\text { Rochester, Min- } \\
\text { nesota (USA) }\end{array}$ & $\begin{array}{l}\text { Videotape ( } 20 \\
\text { min), encour- } \\
\text { aged to watch } \\
\text { once per } 3 \\
\text { months }\end{array}$ & $\begin{array}{l}\text { - Narrator } \\
\text { - Experts in } \\
\text { spine care } \\
\text { - Peer models }\end{array}$ \\
\hline $\begin{array}{l}\text { Steenstra et al., } \\
2006\end{array}$ & $\begin{array}{l}\text { - Graded activity program with exer- } \\
\text { cise quota } \\
\text { - General exercises (endurance and } \\
\text { strengthening) } \\
\text { - Imitation of physical tasks }\end{array}$ & $\begin{array}{l}\text { Operant } \\
\text { conditioning [57] }\end{array}$ & Operant & $\begin{array}{l}\text { Ambulant, } \\
\text { occupational } \\
\text { health service, } \\
\text { (Netherlands) }\end{array}$ & $\begin{array}{l}-1 \text { session } \\
(90 \text { min })-26 \\
\text { sessions }(60 \\
\text { min) }\end{array}$ & Physiotherapist \\
\hline Hay et al., 2005 & $\begin{array}{l}\text { - Development of management plan, } \\
\text { by use of stem and leaf interview } \\
\text { [Main et al., 2002] } \\
\text { - Explanation of pain mechanisms, } \\
\text { distress } \\
\text { - Encouragement of positive coping } \\
\text { strategies } \\
\text { - General fitness and exercise (in clinic, } \\
\text { at home) } \\
\text { - Graded return to usual activities } \\
\text { (pacing) }\end{array}$ & Not reported & $\begin{array}{l}\text { Cognitive- } \\
\text { operant }\end{array}$ & $\begin{array}{l}\text { Ambulant; in } \\
\text { North Stafford- } \\
\text { shire (UK) }\end{array}$ & $\begin{array}{l}-1 \text { session }(40 \\
\min )-6 \text { sessions } \\
(20 \mathrm{~min})\end{array}$ & $\begin{array}{l}\text { Trained mus- } \\
\text { culoskeletal } \\
\text { physiotherapist } \\
\text { ( } 2 \text { day course) }\end{array}$ \\
\hline $\begin{array}{l}\text { Storheim et al., } \\
2003\end{array}$ & $\begin{array}{l}\text { - Functional examination (incl. feed- } \\
\text { back, advice) } \\
\text { - Explanation of pain mechanisms and } \\
\text { how to cope with setbacks } \\
\text { - Activation of M. Transversus Ab- } \\
\text { dominis } \\
\text { - Instruction of lifting techniques } \\
\text { - Emphasizing it is safe to move }\end{array}$ & Not reported & Not CBT & $\begin{array}{l}\text { Ambulant; in } \\
\text { Oslo (Norway) }\end{array}$ & $\begin{array}{l}\text { - Examination- } \\
2 \text { sessions } \\
(30-60 \mathrm{~min})\end{array}$ & $\begin{array}{l}\text { - Physical medi- } \\
\text { cine specialist } \\
\text { (examination) } \\
\text { - Physiothera- } \\
\text { pist }\end{array}$ \\
\hline $\begin{array}{l}\text { Johnstone et al., } \\
2004\end{array}$ & $\begin{array}{l}\text { - Exploration and influencing of } \\
\text { thoughts, beliefs } \\
\text { - Models of pain; factors influencing } \\
\text { pain } \\
\text { - Exercises to exercise quota, pacing of } \\
\text { activities } \\
\text { - Breathing and relaxation techniques }\end{array}$ & Cognitive therapy & $\begin{array}{l}\text { Cognitive- } \\
\text { operant- } \\
\text { respondent }\end{array}$ & $\begin{array}{l}\text { Ambulant; in } \\
\text { Glasgow } \\
\text { (Scotland) }\end{array}$ & $\begin{array}{l}6 \text { sessions } \\
(45 \mathrm{~min})\end{array}$ & Not reported \\
\hline $\begin{array}{l}\text { Gatchel et al., } \\
2003\end{array}$ & $\begin{array}{l}\text { - Education (anatomy, compensation } \\
\text { law, treatment) } \\
\text { - Behaviour skill training in assertive- } \\
\text { ness } \\
\text { - Strengthening and stretching of } \\
\text { back extensors, weight training, and } \\
\text { endurance training } \\
\text { - Occupational therapy (work simula- } \\
\text { tion/ hardening) } \\
\text { - Stress management (monitored by } \\
\text { biofeedback) } \\
\text { - Pain related crisis management }\end{array}$ & $\begin{array}{l}\text { Functional restora- } \\
\text { tion [52] Psychoso- } \\
\text { cial approaches [53] }\end{array}$ & $\begin{array}{l}\text { Cognitive- } \\
\text { respondent }\end{array}$ & $\begin{array}{l}\text { Ambulant; in } \\
\text { Dallas, Texas } \\
\text { (USA) }\end{array}$ & $\begin{array}{l}53 \text { hours per } \\
\text { week, lasting } \\
3 \text { weeks }\end{array}$ & $\begin{array}{l}\text { Multidisci- } \\
\text { plinary team }\end{array}$ \\
\hline
\end{tabular}

${ }^{5}$ Summary of cognitive behavioural therapy based intervention; ${ }^{\pi}$ treatment theory reported in article; ${ }^{\dagger}$ treatment approach classified by review authors; ${ }^{\Omega}$ clinical setting, city and country. 
treatment theories, namely functional restoration treatment [52] and psychosocial approaches. Psychosocial approaches were referenced to a book [53], which summarizes a wide range of CBT-based interventions for chronic LBP patients. Although indicated by name, the intervention was not an operant treatment approach because the program neither comprised exercise quotas or pacing strategies, nor was the functional training explicitly directed towards a pre-defined goal. Significant differences between these two interventions were found in terms of the cognitive treatment approaches. One treatment programme was aimed at exploring and influencing thoughts and beliefs about pain, while the other cognitive treatment approach was comprised of distraction techniques, but did not explicitly indicate which strategies were used and how techniques were applied.

Respondent approaches in the form of biofeedback and relaxation were found in four programmes, always in combination with other interventions. These respondent treatments did not have a reported theoretical justification and the applied techniques were not precisely indicated. One treatment program was not classified as CBT-based treatment, because the treatment theory was not described in the article. In addition the program did not satisfied the basic criteria for being classified as a CBT-based treatment approach.

\section{Discussion}

Eight RCTs with CBT-based treatment programmes were included in this systematic review. Included trials suffered partially from high risk of bias. However, in general there was significant heterogeneity in the domains related to patient selection, treatment design, control groups, and outcome measures. These findings of heterogeneity, particularly in domain of treatment design, confirmed the methodological appropriateness of this systematic review, with its primary focus on the analysis of treatment theory instead of a conventional quantitative analysis of outcomes. Only one operant treatment approach was based on a traceable, explicitly described treatment theory which was sufficient for understanding the treatment processes and mechanisms.

\section{Methodological properties}

Analysis of CBT-based treatment strategies was limited to the eight included RCTs. It can be argued that the applied inclusion criteria were too strict with regard to the patient selection, considering that a total of 55 articles (21\%) were excluded because of chronic LBP of more than 12 weeks duration or inaccurate reporting of the pain duration. Inclusion of a homogenous patient population has methodological advantages for a systematic review, but results, within this research, in a loss of potentially promising treatment strategies. Generally, stratification of patients with non-specific LBP into subgroups of acute/sub-acute and chronic LBP based on the duration of the current pain episode is questionable [54]. A large prospective cohort study investigating physical, psychological and social variables showed that acute/sub-acute and chronic LBP patients differ in all physical and most psychological variables but not in fear of pain and fear avoidance [55]. These findings indicate that treatments applied in chronic LBP may also be promising for influencing psychosocial obstacles to recovery from acute/sub-acute LBP. However, we decided not to include a mixed patient population, since alternative cut-off points for patient stratification remain unclear and including chronic LBP patients without maximum pain duration is not appropriate.

Identification of those patients with present obstacles to recover from acute/sub-acute LBP that is for those who, hypothetically, may have the greatest benefit of CBT-based interventions, is a challenge for both the design of clinical trials and for clinical practice [23]. Two different measurements were used in the included RCTs for selecting patients at risk for developing chronicity, but both with their limitations. To the best knowledge of the authors, the Identification Algorithm for Chronic Disability [47] has not been published in its final version as a short assessment battery. The other instrument used to evaluate somatic distress, consisted of two questionnaires, namely the Modified Somatic Perception Questionnaire (MSPQ) and the Modified Zung Depression Index (Modified Zung) [48]. It was shown that LBP patients with somatic distress have a 5.3 times greater risk of a poor outcome on disability when compared with normal LBP patients [48]. However, cut-off scores in the included RCT were lower than in the validated version of the questionnaire, and reasons for this deviation were not reported. In general, the detected heterogeneity in patient selection between the included RCTs reflects the challenge of the patient selection in nonspecific LBP and indicates the importance of careful consideration of this issue for the future study design as well as in clinical practice.

Heterogeneity in outcome measures restricts the comparison and quantitative analysis of treatment outcomes and of its efficacy. It has been recommended that outcome measures should be integrated for the following domains of low back pain; pain intensity, function, generic health status or wellbeing, disability, and patient satisfaction $[37,56]$.

\section{Treatment strategies and theoretical justification}

Graded activity, structured by exercise quota with the timecontingency principle, is based on the explicitly described treatment theory. This concept explains how pain and its related pain behaviours (e.g. physical inactivity, complaining and/or absence from work) are controlled by learning (operant conditioning [29,57]. Therefore, positive reinforcement of exercise behaviour may lead to a decrease in pain behaviour. In the graded activity program, patients are primarily educated that pain does hurt, but that this does not mean it harms. Afterwards, within three treatment sessions, patients perform general exercises and individually tailored exercises until their pain tolerance is reached. The average activity level is then used as baseline value for the quota-based exercise program. In the following step, the patient, together with the therapist, determines a gradually increasing quota for each exercise where the quota starts at a level below the baseline value. Quotas are pre-set and not subject to change during the course of the program, regardless of the level of pain. Graded activity programmes with similar principles of operant conditioning, with slightly different exercise quotas were applied to chronic 
LBP patients [58-60]. In general, standardization of exercise quotas requires careful consideration, and in clinical practice it may be advisable to tailor the increase of exercise quotas to patients' individual capacities, whereby the progression needs to be pre-set and gradually increased towards a defined goal. Treatment intensity between the different graded activity programmes varied from 8 up to 26 sessions, each lasting between 45 and $60 \mathrm{~min}$. Recommendation regarding best treatment intensity is not available. However, it can be assumed that an intensity of approximately 26 sessions is appropriate when considering the time requirements for patient education, goal setting, defining baseline values and the gradual increase of exercise quotas. Graded exposure, referred to as graded exposure in vivo, is a similar treatment approach that is especially tailored to patients with high levels of pain-related fear [25]. In graded exposure treatment, patients are primarily asked to create a hierarchy of feared activities. Exposure to these activities occurs in a hierarchical fashion, starting with the least fearful activity and further with a gradually progressing to the most feared situations [61]. Graded activity and graded exposure are both based on the principles of operant conditioning. Graded activity has the patient's functional ability as its primary approach while graded exposure is primarily directed at pain cognitions and fear-avoidance beliefs. A systematic review compared the overall effect of graded activity versus graded exposure on pain as well as on disability and found no significant difference in effect sizes between these two interventions for chronic non-specific LBP [62]. Graded activity is simpler to integrate into physiotherapy practice as physiotherapists have expertise in maintaining and restoring functional ability and are experienced in providing therapeutic exercises and functional training. On the contrary graded exposure, with its focus predominantly on pain cognitions and emotions, is more challenging for physiotherapists without additional training. This reasoning was recently underpinned by Foster and Delitto, they suggested that psychosocial factors, such as positive reinforcement, enhancing personal control and self-efficacy, and reducing fear of movement can be relatively easily be incorporated in physiotherapy while eliciting and addressing unhelpful cognitions and low mood requires additional training for physiotherapists [24].

Cognitive therapy approaches comprise several different therapeutic patient education programmes. These identified patient education strategies aim to modify maladaptive conceptualizations and dysfunctional beliefs about pain, but it is not explained how these strategies may counter such negative cognitions in acute/sub-acute LBP. The distraction technique was integrated in multidisciplinary treatment programmes. It was not reported how this cognitive treatment strategy was applied, but despite the absence of clear information, it can be assumed that clinical psychologists or other mental health care specialists provided the intervention. The reported theoretical justifications of cognitive treatment approaches are based on broad summaries of CBT-based treatment strategies. In general, treatment theory of the detected cognitive treatment approaches is insufficient for explaining treatment mechanisms and processes, as well as for understanding how these strategies may influence patients' thoughts, beliefs and emotions. As a consequence, it remains unclear how physiotherapists can integrate cognitive treatment strategies into ambulant clinical practice. Respondent treatment approaches in the form of relaxation and biofeedback are already used in standard physiotherapy practice. However, as in the case for cognitive treatment approaches, it is unclear how these strategies address psychosocial obstacles to recovery in acute/subacute LBP such as fear-avoidance beliefs, catastrophizing or depression. Therefore, it may be indispensable to search for alternative promising cognitive and respondent treatment approaches, which were applied in patient populations with similar patient characteristics such as chronic LBP, neck pain, fibromyalgia or chronic fatigue syndrome. But transferring interventions from one patient population to another is complex and requires additional systematic analyses.

Identified CBT-based treatment programmes were primarily provided by physiotherapists. Aside from other clinical psychologists, other health care providers involved in the management of non-specific LBP are also challenged to integrate CBT-based interventions in their routine pain management. Such professionals should include occupational therapists, chiropractors, nurses or general practitioners. Hypothetically, these professionals should also be able to integrate graded activity strategies into their clinical practice. However, the professional background and clinical setting of these health care providers differs substantially. Therefore, conclusions about the applicability of CBT-based approaches in different treatment settings need to be based on further systematic analyses of each particular profession.

\section{Conclusion}

Physiotherapists can integrate graded activity into their standard pain management for acute/sub-acute, non-specific LBP. This CBT-based treatment approach, based on principles of operant conditioning, is promising for the promotion of health behaviour or active coping strategies, which may have a positive impact on obstacles to recovery from LBP such as catastrophizing and fear-avoidance beliefs. More high quality RCTs with explicitly described theoretical justifications of the intervention are required for the future analysis of treatment efficacy, and especially RCTs which include comprehensive measures of all domains of LBP outcomes.

Declaration of Interest: The authors report no conflict of interest, and the research project received no funding.

\section{References}

1. Hoy D, Brooks P, Blyth F, Buchbinder R. The Epidemiology of low back pain. Best Pract Res Clin Rheumatol 2010;24:769-781.

2. Croft PR, Macfarlane GJ, Papageorgiou AC, Thomas E, Silman AJ. Outcome of low back pain in general practice: a prospective study. BMJ 1998;316:1356-1359.

3. Gurcay E, Bal A, Eksioglu E, Hasturk AE, Gurcay AG, Cakci A. Acute low back pain: clinical course and prognostic factors. Disabil Rehabil 2009;31:840-845. 
4. Hashemi L, Webster BS, Clancy EA. Trends in disability duration and cost of workers' compensation low back pain claims (1988-1996). J Occup Environ Med 1998;40:1110-1119.

5. Katz JN. Lumbar disc disorders and low-back pain: socioeconomic factors and consequences. J Bone Joint Surg Am 2006;88 Suppl 2:21-24.

6. Jamison RN. 2011. Nonspecific treatment effects in pain medicine. Pain: Clinical Updates [Internet] 2011 [cited 2011 April 26]; Volume XIX: Issue 2. Available from: http://www.iasp-pain.org/AM/Template. $\mathrm{cfm}$ ?Section=Publications

7. van Tulder M, Becker A, Bekkering T, Breen A, del Real MT, Hutchinson A, Koes B, et al.; COST B13 Working Group on Guidelines for the Management of Acute Low Back Pain in Primary Care. Chapter 3. European guidelines for the management of acute nonspecific low back pain in primary care. Eur Spine J 2006;15 Suppl 2:S169-S191.

8. Chou R, Loeser JD, Owens DK, Rosenquist RW, Atlas SJ, Baisden J, Carragee EJ, et al.; American Pain Society Low Back Pain Guideline Panel. Interventional therapies, surgery, and interdisciplinary rehabilitation for low back pain: an evidence-based clinical practice guideline from the American Pain Society. Spine 2009;34:1066-1077.

9. Koes BW, van Tulder M, Lin CW, Macedo LG, McAuley J, Maher C. An updated overview of clinical guidelines for the management of nonspecific low back pain in primary care. Eur Spine J 2010;19:2075-2094.

10. Cohen SP, Argoff CE, Carragee EJ. Management of low back pain. BMJ [Internet]. 2008 [cited 2011 December 07]; 337:a2718. Available from: http://www.bmj.com/content/337/bmj.a2718?view=long\&p mid=19103627

11. Waddell G. The back pain revolution. 2nd ed. Edinburgh; Churchill Livingstone, 2004.

12. WHO. International classification of functioning, disability and health: ICF. Geneva; WHO, 2001.

13. Vlaeyen JW, Linton SJ. Fear-avoidance and its consequences in chronic musculoskeletal pain: a state of the art. Pain 2000;85:317-332.

14. Picavet HS, Vlaeyen JW, Schouten JS. Pain catastrophizing and kinesiophobia: predictors of chronic low back pain. Am J Epidemiol 2002;156:1028-1034.

15. Boersma K, Linton SJ. Psychological processes underlying the development of a chronic pain problem: a prospective study of the relationship between profiles of psychological variables in the fearavoidance model and disability. Clin J Pain 2006;22:160-166.

16. Grotle M, Vøllestad NK, Brox JI. Clinical course and impact of fearavoidance beliefs in low back pain: prospective cohort study of acute and chronic low back pain: II. Spine 2006;31:1038-1046.

17. Iles RA, Davidson M, Taylor NF. Psychosocial predictors of failure to return to work in non-chronic non-specific low back pain: a systematic review. Occup Environ Med 2008;65:507-517.

18. Dawson AP, Schluter PJ, Hodges PW, Stewart S, Turner C. Fear of movement, passive coping, manual handling, and severe or radiating pain increase the likelihood of sick leave due to low back pain. Pain 2011;152:1517-1524.

19. Neubauer E, Junge A, Pirron P, Seemann H, Schiltenwolf M. HKF-R 10 - screening for predicting chronicity in acute low back pain (LBP): a prospective clinical trial. Eur J Pain 2006;10:559-566.

20. Henschke N, Maher CG, Refshauge KM, Herbert RD, Cumming RG, Bleasel J, York J, et al. Prognosis in patients with recent onset low back pain in Australian primary care: inception cohort study. BMJ 2008;337:a171.

21. Burton AK, Balagué F, Cardon G, Eriksen HR, Henrotin Y, Lahad A, Leclerc A, et al.; COST B13 Working Group on Guidelines for Prevention in Low Back Pain. Chapter 2. European guidelines for prevention in low back pain: November 2004. Eur Spine J 2006;15 Suppl 2:S136-S168.

22. World Confederation for Physical Therapy [Internet]. Policy statement: description of physical therapy; [cited 2011 Dec 06]. Available from: http://www.wcpt.org/policy/ps-descriptionPT

23. van der Windt D, Hay E, Jellema P, Main C. Psychosocial interventions for low back pain in primary care: lessons learned from recent trials. Spine 2008;33:81-89.

24. Foster NE, Delitto A. Embedding psychosocial perspectives within clinical management of low back pain: integration of psychosocially informed management principles into physical therapist practice-challenges and opportunities. Phys Ther 2011;91:790-803.

25. Giaquinto S, Bruti L, Dall'Armi V, Gison A, Palma E. A bio-psychosocial approach for treating sub-acute low back pain. Disabil Rehabil 2010;32:1966-1971.

26. Airaksinen O, Brox JI, Cedraschi C, Hildebrandt J, Klaber-Moffett J, Kovacs F, Mannion AF, et al.; COST B13 Working Group on Guidelines for Chronic Low Back Pain. Chapter 4. European guidelines for the management of chronic nonspecific low back pain. Eur Spine J 2006;15 Suppl 2:S192-S300.

27. Henschke N, Ostelo RW, van Tulder MW, Vlaeyen JW, Morley S, Assendelft WJ, Main CJ. Behavioural treatment for chronic low-back pain. Cochrane Database Syst Rev 2010;7:CD002014.

28. Vlaeyen JW, Haazen IW, Schuerman JA, Kole-Snijders AM, van Eek $\mathrm{H}$. Behavioural rehabilitation of chronic low back pain: comparison of an operant treatment, an operant-cognitive treatment and an operantrespondent treatment. Br J Clin Psychol 1995;34 (Pt 1):95-118.

29. Ferster CB, Skinner BF. Schedules of reinforcement. New York: Appleton-Century-Crofts, Inc, 1957.

30. Sanders SH. Operant conditioning with chronic pain: back to basics. In: Turk DC, Gatchel RJ. Psychological approaches to pain management: a practitioner's handbook. 2nd ed. New York: The Guilford Press, 2002. p 128-137.

31. Beck A, Rush J, Shaw B, Emery G. Cognitive therapy of depression. New York: The Guilford Press, 1979.

32. Winterowd C, Beck AT, Gruener D. Cognitive therapy with chronic pain patients. New York: Springer Publishing Company, 2003.

33. Turner JA, Jensen MP. Efficacy of cognitive therapy for chronic low back pain. Pain 1993;52:169-177.

34. Syrjala KL, Abrams JR. Hypnosis and imagery in the treatment of pain. In: Turk DC, Gatchel RJ. Psychological approaches to pain management: a practitioner's handbook. 2nd ed. New York: The Guilford Press, 2002. p 187-209.

35. Lettinga AT, van Twillert S, Poels BJ, Postema K. Distinguishing theories of dysfunction, treatment and care. Reflections on 'describing rehabilitation interventions'. Clin Rehabil 2006;20:369-374.

36. Siemonsma PC, Schröder CD, Roorda LD, Lettinga AT. Benefits of treatment theory in the design of explanatory trials: cognitive treatment of illness perception in chronic low back pain rehabilitation as an illustrative example. J Rehabil Med 2010;42:111-116.

37. Deyo RA, Battie M, Beurskens AJ, Bombardier C, Croft P, Koes B, Malmivaara A, et al. Outcome measures for low back pain research. A proposal for standardized use. Spine 1998;23:2003-2013.

38. Furlan AD, Pennick V, Bombardier C, van Tulder M; Editorial Board, Cochrane Back Review Group. 2009 updated method guidelines for systematic reviews in the Cochrane Back Review Group. Spine 2009;34:1929-1941.

39. Gatchel RJ, Polatin PB, Noe C, Gardea M, Pulliam C, Thompson J. Treatment- and cost-effectiveness of early intervention for acute lowback pain patients: a one-year prospective study. J Occup Rehabil 2003;13:1-9.

40. Johnstone R, Donaghy M, Martin D. A pilot study of a cognitive-behavioural therapy approach to physiotherapy, for acute low back pain patients, who show signs of developing chronic pain. Adv Physiother. 2004;2:182-188.

41. Storheim K, Brox JI, Holm I, Koller AK, Bø K. Intensive group training versus cognitive intervention in sub-acute low back pain: short-term results of a single-blind randomized controlled trial. J Rehabil Med 2003;35:132-140.

42. Hay EM, Mullis R, Lewis M, Vohora K, Main CJ, Watson P, Dziedzic KS, et al. Comparison of physical treatments versus a brief pain-management programme for back pain in primary care: a randomised clinical trial in physiotherapy practice. Lancet 2005;365:2024-2030.

43. Steenstra IA, Anema JR, van Tulder MW, Bongers PM, de Vet HC, van Mechelen W. Economic evaluation of a multi-stage return to work program for workers on sick-leave due to low back pain. J Occup Rehabil 2006;16:557-578.

44. Newcomer KL, Vickers Douglas KS, Shelerud RA, Long KH, Crawford B. Is a videotape to change beliefs and behaviors superior to a standard videotape in acute low back pain? A randomized controlled trial. Spine J 2008;8:940-947.

45. Whitfill T, Haggard R, Bierner SM, Pransky G, Hassett RG, Gatchel RJ. Early intervention options for acute low back pain patients: a randomized clinical trial with one-year follow-up outcomes. J Occup Rehabil 2010;20:256-263.

46. Rogerson MD, Gatchel RJ, Bierner SM. A cost utility analysis of interdisciplinary early intervention versus treatment as usual for high-risk acute low back pain patients. Pain Pract 2010;10:382-395.

47. Gatchel RJ, Polatin PB, Mayer TG. The dominant role of psychosocial risk factors in the development of chronic low back pain disability. Spine 1995;20:2702-2709.

48. Main CJ, Wood PL, Hollis S, Spanswick CC, Waddell G. The Distress and Risk Assessment Method. A simple patient classification to identify distress and evaluate the risk of poor outcome. Spine 1992;17: $42-52$. 
49. Million R, Hall W, Nilsen KH, Baker RD, Jayson MI. Assessment of the progress of the back-pain patient 1981 Volvo Award in Clinical Science. Spine 1982;7:204-212.

50. Roland M, Morris R. A study of the natural history of back pain. Part I: development of a reliable and sensitive measure of disability in low-back pain. Spine 1983;8:141-144

51. Roland M, Waddell G, Klaber-Moffatt J, Burton K, Main C, Cantrell E. The Back Book. 2nd ed. London: The Stationary Office, 2002.

52. Hazard RG, Fenwick JW, Kalisch SM, Redmond J, Reeves V, Reid S, Frymoyer JW. Functional restoration with behavioral support. A oneyear prospective study of patients with chronic low-back pain. Spine 1989;14:157-161.

53. Turk DC, Gatchel RJ. Psychological approaches to pain management: a practitioner's handbook. 2nd ed. New York: The Guilford Press, 2002. p 128-137.

54. Dunn KM, Croft PR. The importance of symptom duration in determining prognosis. Pain 2006;121:126-132.

55. Grotle M, Foster NE, Dunn KM, Croft P. Are prognostic indicators for poor outcome different for acute and chronic low back pain consulters in primary care? Pain 2010;151:790-797.

56. Bombardier C. Outcome assessments in the evaluation of treatment of spinal disorders: summary and general recommendations. Spine 2000;25:3100-3103.
57. Staal JB, Hlobil H, Twisk JW, Smid T, Köke AJ, van Mechelen W. Graded activity for low back pain in occupational health care: a randomized, controlled trial. Ann Intern Med 2004;140:77-84.

58. Woods MP, Asmundson GJ. Evaluating the efficacy of graded in vivo exposure for the treatment of fear in patients with chronic back pain: a randomized controlled clinical trial. Pain 2008;136:271-280.

59. George SZ, Zeppieri G Jr, Cere AL, Cere MR, Borut MS, Hodges MJ, Reed DM, et al. A randomized trial of behavioral physical therapy interventions for acute and sub-acute low back pain (NCT00373867). Pain 2008;140:145-157.

60. Leeuw M, Goossens ME, van Breukelen GJ, de Jong JR, Heuts PH, Smeets RJ, Köke AJ, Vlaeyen JW. Exposure in vivo versus operant graded activity in chronic low back pain patients: results of a randomized controlled trial. Pain 2008;138:192-207.

61. Vlaeyen JW, de Jong J, Sieben J, Crombez G. Graded exposure in vivo for pain-related fear. In: Turk DC, Gatchel RJ. Psychological approaches to pain management: a practitioner's handbook. 2nd ed. New York: The Guilford Press, 2002. p 210-233.

62. Macedo LG, Smeets RJ, Maher CG, Latimer J, McAuley JH. Graded activity and graded exposure for persistent nonspecific low back pain: a systematic review. Phys Ther 2010;90: 860-879. 